females raised from isolated mothers in the greenhouse. The matings and results were as follows, the letters showing the color characters which were visible:

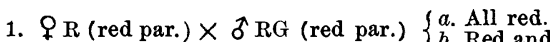

2. $q_{\mathrm{GR}}$ (green par.) $\times \widehat{\delta} \mathrm{G}$ (green par.) $\{$ All green.

3. $9 \mathrm{R}$ (red par.) $\times \delta \mathrm{G}$ (green par.) $\{$ No eggs hatched.

4. $\$$ GR (green par.) $\times \widehat{\sigma} \mathrm{RG}$ (red par) $\left\{\begin{array}{l}a . \text { One red. } \\ b . \text { Several green. }\end{array}\right.$

Only a small proportion of the eggs hatched, but the results, though meager, indicate the possibility that color inheritance may here be Mendelian, and that a further study of it may throw light on the problem of sex inheritance.

The coloration of the sexual generation, however, shows that either one or the other of two conditions must probably exist: (1) All of the egg-ancestors and therefore all of the parthenogenetic individuals, as well as the males and females, are sex-hybrids as well as color-hybrids, and the factors which determine sex dominance also determine color dominance, possibly by virtue of some structural correlation of the two characters. (2) There are green hybrid strains which produce red females and red hybrid strains which produce greenish-brown males, while the red strains which produce red females may be pure reds and the green strains which produce green males may be pure greens.

The first of these suppositions, which alone could account for the conditions found in the star cucumber aphid, where parthenogenetic mothers of either color produce both red males and green females, and in the goldenrod aphid where the brown parthenogenetic mothers produce both green males and brown females, seems much more likely to be true for all.

In the following table the possibilities for the star cucumber aphid are shown under I., and those for the Enothera aphid under I. and II. combined. (The color scheme must be reversed for the star cucumber aphid, Go, Ro.) In both, the dominance of sometimes one color, sometimes the other in the parthenogenetic generations is a subject for investigation. It may be conditioned by the immediate ancestry of the gametes.

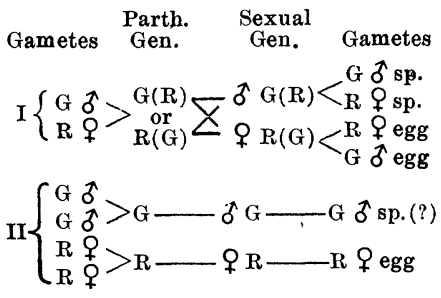

In the goldenrod aphid, if we consider the parthenogenetic forms as essentially female, correlation of color with sex (B $q$ and $G \delta^{*}$ ), and selective fertilization would account for the observed relation of color to sex.

The second, and less likely but nevertheless interesting, possibility for the CEnothera aphid involves the question whether a zygote can be pure as to the sex character, or unisexual. The chief point to be investigated by experiment, in addition to the study of color inheritance in cross-breeding, is whether in this aphid both males and females come from the parthenogenetic progeny of each egg-ancestor, or in some cases ( $\left.G \delta^{7}\right)$ only males, and in others $(\mathrm{R}+)$ only females. To test this possibility it would be necessary to carry many families through from the egg to the following sexual generation, and very likely to repeat the experiment several times.

A large series of experiments in cross-breeding to test the color inheritance has been planned by the author for next year, and this note is published in the hope that some one may be interested to undertake experiments along the same line.

Bryn Mawr College,

Bryn Mawr, Pa., June 8, 1907

\section{A COLOR SPORT AMONG THE LOCUSTIDE}

There are various sports among animals that are so rarely observed and so little understood as to seem to render it desirable that every occurrence should be recorded. One of these is the occasional substitution of pink for green color among the Locustidæ, which has been recorded perhaps a dozen times. It is to be hoped that repeated notices of their capture may call the attention of physiologists to them, and in time elicit a satisfactory explanation of the phenomenon. A specimen of 
one of these pink katydids, a male of the species Amblycorypha oblongifolia (De Geer), identified by Jas. A. G. Rehn, was sent to the Museum of the University of Michigan some months ago, by Mr. A. S. Austin. He captured the insect on Grosse Isle, in the Detroit River, some twelve or fifteen miles below Detroit, on August 12, 1906. This specimen is of duller colors than the ones figured by Scudder, ${ }^{1}$ but is still - a decided pink. The brown spots on the tegmina are fainter, twelve or thirteen in number, and less scattered than in Scudder's specimens, and are roughly arranged in two rows on the lower two thirds of the wings. The yellow flecks mentioned by Scudder are wanting.

The stridulating area, like that of Scudder's specimen, is brown except a small trapeziform area at the angle of the wing, which is pink. The eyes are brownish red, margined with yellow. The antennæ are yellow, inclined to brown in the distal half. The sides of the thorax, all of the coxæ, and the proximal fourth of the hind femora are tinged with green.

Besides this specimen there is also in the University Museum a female of the same species, without data, which has also duller colors than the female of Scudder's plate. This dullness can hardly be attributed to a fading in the preserved specimen, for the male was received alive, and up to the present time has preserved its colors perfectly.

Folsom ${ }^{2}$ has been led to remark that these pink specimens are found in late summer, as if to suggest that the change may be at least in part due to seasonal influence. If this statement is meant to apply to adults only, the earlier dates, August 9 for one of Scudder's specimens and August 12 for Austin's, can hardly be considered late records. If the replacement occurs also in nymphs, of which $I$ find no record in the accessible literature, then the earliest records

\footnotetext{
${ }^{1}$ Scudder, S. H., 'Pink Grasshoppers,' Entomological News, Vol. XII., No. 5, May, 1901, pp. 129-131, and Pl. VI.

'Folsom, J. W., 'Entomology with Reference to its' Biological and Economic Aspects,' p. 215.
}

are comparatively late, and Folsom's suggestion is of some force. It would be gratifying to learn the dates of other unrecorded specimens.

UNIVERSTTY MUSEUM, University OF Mrchigan

\section{GYMNOSPORANGIUM MACROPUS}

During the last few years the cedar rust has increased in abundance and severity in $\mathrm{Ne}-$ braska and adjacent states. The disease has been so severe that it has threatened the life of the cedars in many places where they have been employed as wind-breaks around orchards or where they were adjacent to apple trees that were susceptible to infection.

Spraying experiments have shown that the disease may be at least partially controlled on the apple, but those who have cedars-and there are many in this section who value them as much as they do their apple treeshave been clamoring for assistance in saving them from the inroads of this fungus.

As a result of this demand careful observations have been made on the life history of this rust and spraying experiments are in progress. The work was started with the supposition that the spores of the cluster-cups on the apple leaves and fruit produced the cedar apples which matured in the autumn of the same season, but observations and experiments have not confirmed this assumption.

Observations made during the summer of 1906 showed that the first cluster-cups matured on the apple about the first of July in the vicinity of Lincoln. At this date only a very few cluster-cups were open and these were mostly on the fruit where two or more apples were in contact. $\bar{A}$ few days later young cedar apples as large as radish seeds were found to be present on the cedars. At Broken Bow, Custer County, the first mature cluster-cups were not observed until the eighth of July, and at that time cedar apples were found in abundance varying in size from one twelfth to one fourth inch in diameter.

Careful watch has been kept of the cedars during the present season. The first indication of the presence of the young cedar apples 